\title{
Analisis Kestabilan dan Kontrol Optimal Model Matematika Penyebaran Penyakit Ebola dengan Penanganan Medis
}

\author{
Sofita Suherman ${ }^{1}$, Fatmawati ${ }^{2, *} \&$ Cicik Alfiniyah ${ }^{3}$ \\ ${ }^{1,2,3}$ Departemen Matematika, Fakultas Sains dan Teknologi, Kampus C \\ Universitas Airlangga, Jl. Mulyorejo, Surabaya \\ *Corresponding author: fatmawati@fst.unair.ac.id
}

\begin{abstract}
Ebola disease is one of an infectious disease caused by a virus. Ebola disease can be transmitted through direct contact with Ebola's patient, infected medical equipment, and contact with the deceased individual. The purpose of this paper is to analyze the stability of equilibriums and to apply the optimal control of treatment on the mathematical model of the spread of Ebola with medical treatment. Model without control has two equilibria, namely non-endemic equilibrium $\left(E_{0}\right)$ and endemic equilibrium $\left(E_{1}\right)$. The existence of endemic equilibrium and local stability depends on the basic reproduction number $\left(R_{0}\right)$. The non-endemic equilibrium is locally asymptotically stable if $R_{0}<1$ and endemic equilibrium tend to asymptotically stable if $R_{0}>1$. The problem of optimal control is then solved by Pontryagin's Maximum Principle. From the numerical simulation result, it is found that the control is effective to minimize the number of the infected human population and the number of the infected human with medical treatment population compare without control.
\end{abstract}

Keywords: mathematical model; Ebola disease; medical treatment; stability; optimal control.

\section{Pendahuluan}

Berbagai penyakit disebabkan oleh virus, bakteri dan berbagai hal. Penyakit ebola merupakan salah satu penyakit yang disebabkan oleh virus. Virus ebola dari genus Ebolavirus dan familia Filoviridae adalah virus yang menyebabkan penyakit ebola. Penyakit ebola ini pertama kali muncul pada tahun 1976 di Sudan, dan Yambuku, Kongo serta terjadi di desa sekitar sungai Ebola, sehingga menjadikan nama penyakit ini [1].

Masa inkubasi dari virus ebola terjadi antara 2 hingga 21 hari [2]. Gejala awal penderita ebola berupa demam mendadak, sakit kepala, nyeri otot, dan menggigil. Penderita ebola bisa mengalami pendarahan internal yang mengakibatkan diare, muntah, batuk darah, kegagalan organ hingga kematian. Resiko kematian dari penyakit ebola ini cukup tinggi berkisar antara 50-90\% pada manusia [1].

Penanganan untuk penyakit ebola dengan cara pemberian oralit yang mengandung elektrolit, karena hingga saat ini masih dilakukan penelitian untuk obat yang efektif dalam menyembuhkan penyakit ini. Penanganan medis pada pasien adalah perawatan intensif 
dalam penguatan sistem imun penderita agar tidak menimbulkan kegagalan fungsi organ pada pasien [1].

Penyebaran penyakit ebola terbesar terjadi di Afrika Barat terutama di Guinea, Liberia dan SierraLeone [2]. Penularan penyakit ini disebabkan oleh adanya kontak langsung dengan cairan tubuh, sekresi, organ-organ, darah, dan permukaan dari barang-barang yang terkontaminasi. Penularan tidak hanya terjadi dari penderita yang masih hidup, penderita yang telah meninggal juga dapat menularkan penyakit. Hal ini mengakibatkan penguburan yang benar oleh pihak medis sangat penting dalam pencegahan penularan penyakit [1]. Penularan juga dapat terjadi melalui pasien yang dirawat di rumah sakit diakibatkan buruknya teknik perawatan dan penggunaan peralatan rumah sakit yang kurang baik [3].

Seiring berjalannya waktu, pemodelan matematika telah banyak digunakan dalam hal kesehatan, termasuk penyebaran penyakit ebola. Beberapa peneliti telah menkontruksi model matematika penyebaran penyakit ebola. Do dkk (2016) dalam [4] telah mengkaji model matematika penyebaran penyakit ebola dengan memperhatikan empat populasi yaitu Susceptible-Latent-Infected-Recovered-Deaths dan tanpa pemberian kontrol. Peneliti lain juga telah mempelajari model matematika penyebaran penyakit ebola dengan pengaruh lain, seperti populasi penderita yang kambuh dan kembali terinfeksi oleh Agusto (2017) [5]. Model yang digunakan terdiri dari beberapa kompartemen yaitu Susceptible-Exposed-Infected (early-stage dan late-stage)-Recovered-Deceased. Diaz dkk (2018) dalam [6] juga membahas model matematika penyebaran penyakit ebola di Afrika Barat, lebih khususnya model yang dibahas dengan memperhatikan pengaruh penanganan medis.

Pada paper ini akan dibahas model matematika penyebaran penyakit ebola dengan penanganan medis yang merupakan hasil modifikasi dari model yang telah dikembangkan oleh Diaz dkk (2018) [6]. Modifikasi model yang dilakukan adalah memperhatikan laju kelahiran dan kematian serta penambahan variabel kontrol berupa upaya pengobatan. Berdasarkan model yang digunakan dalam penelitian ini akan dianalisis kestabilan titik setimbang dan analisis kontrol optimal baik secara analitik maupun numeric pada model matematika penyebaran penyakit Ebola dengan penanganan medis.

\section{Formulasi Model}

Pada bagian ini akan diformulasikan model matematika penyebaran penyakit ebola dengan penanganan medis. Adapun asumsi yang digunakan untuk kontruksi model sebagai berikut :

a. Populasi manusia yang terpapar virus ebola tidak dapat menularkan penyakit.

b. Individu yang sembuh dianggap kebal terhadap penyakit. 
c. Individu yang terinfeksi dan mati dengan tidak dikubur dengan baik dapat menularkan penyakit.

d. Individu yang terinfeksi dan mendapat penanganan di rumah sakit dapat menularkan penyakit.

e. Individu yang terinfeksi dan mendapat penanganan di rumah sakit memiliki peluang sembuh yang lebih besar dari individu yang terinfeksi namun tidak mendapat penanganan di rumah sakit.

f. Individu yang terinfeksi dan mendapat penanganan di rumah sakit ketika mati dapat langsung dikuburkan dengan baik.

g. Individu yang terinfeksi dan mati memerlukan waktu untuk dapat dikuburkan dengan baik.

Populasi manusia dibagi menjadi tujuh kompartemen yaitu populasi manusia yang rentan terhadap virus ebola $(S)$, populasi manusia yang terpapar virus ebola $(E)$, populasi manusia yang terinfeksi virus ebola $(I)$, populasi manusia yang terinfeksi virus ebola dan mendapat penanganan di rumah sakit $(H)$, populasi manusia yang terinfeksi virus ebola dan mati dengan belum dikuburkan dengan baik $\left(R_{I}\right)$, populasi manusia yang terinfeksi virus ebola dan mati dengan dikuburkan dengan baik $\left(R_{B}\right)$, dan populasi manusia yang sembuh $\left(R_{R}\right)$. Pendefinisian parameter dapat dilihat pada Tabel 1 berikut.

Tabel 1. Pendefinisian Parameter Model

\begin{tabular}{|c|c|}
\hline Notasi & Keterangan \\
\hline$\Lambda$ & Laju kelahiran \\
\hline$\beta_{1}$ & $\begin{array}{l}\text { Laju transmisi antara populasi rentan dan populasi yang terinfeksi virus } \\
\text { ebola }\end{array}$ \\
\hline$\beta_{2}$ & $\begin{array}{l}\text { Laju transmisi antara populasi rentan dan populasi yang terinfeksi dan } \\
\text { mati dengan belum dikuburkan dengan baik }\end{array}$ \\
\hline$\beta_{3}$ & $\begin{array}{l}\text { Laju transmisi antara populasi rentan dan populasi yang terinfeksi dan } \\
\text { mendapat penanganan di rumah sakit }\end{array}$ \\
\hline$\delta$ & Masa inkubasi \\
\hline$\gamma_{1}$ & $\begin{array}{l}\text { Laju rata-rata penyakit pada individu yang terinfeksi tanpa penanganan di } \\
\text { rumah sakit }\end{array}$ \\
\hline$\gamma_{2}$ & $\begin{array}{l}\text { Laju rata-rata penyakit pada individu yang terinfeksi dengan penanganan } \\
\text { di rumah sakit }\end{array}$ \\
\hline$\psi$ & $\begin{array}{l}\text { Laju rata-rata individu yang terinfeksi menjadi individu terinfeksi dan } \\
\text { mendapat penanganan di rumah sakit }\end{array}$ \\
\hline$\rho_{1}$ & $\begin{array}{l}\text { Probabilitas individu mati karena penyakit tanpa penanganan di rumah } \\
\text { sakit }\end{array}$ \\
\hline$\rho_{2}$ & $\begin{array}{l}\text { Probabilitas individu mati karena penyakit dengan penanganan di rumah } \\
\text { sakit }\end{array}$ \\
\hline$\omega$ & $\begin{array}{l}\text { Rata-rata waktu individu terinfeksi yang mati sampai dikuburkan dengan } \\
\text { baik }\end{array}$ \\
\hline$\mu$ & Laju kematian alami \\
\hline
\end{tabular}


Berdasarkan asumsi dan pendefinisian parameter serta variabel dapat dibentuk diagram transmisi penyebaran penyakit ebola dengan penanganan medis yang disajikan pada Gambar 1 sebagai berikut.

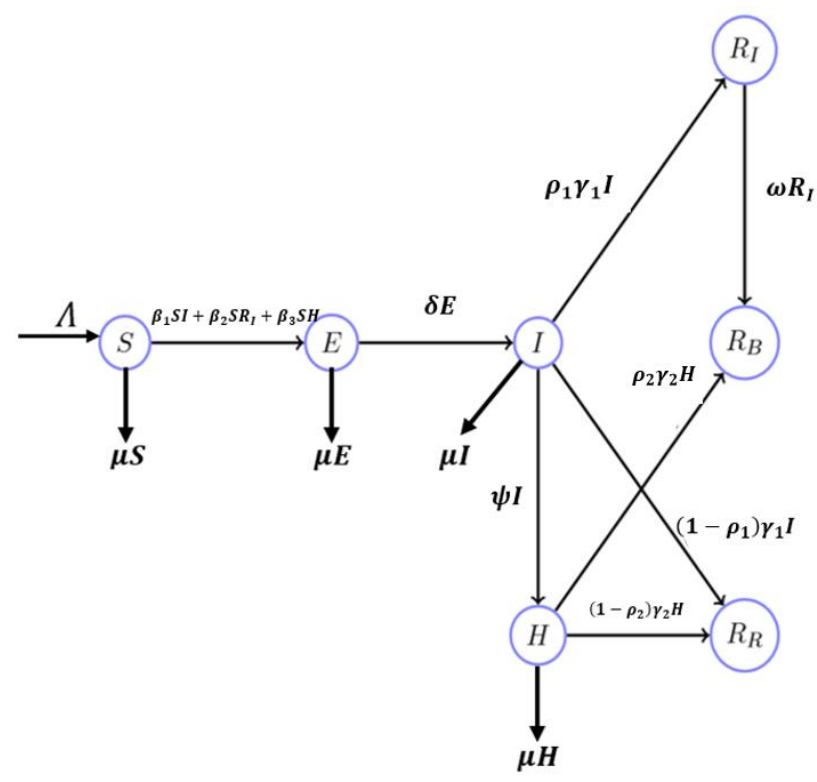

Gambar 1. Diagram Transmisi Model

Dari diagram transmisi pada Gambar 1 dapat diformulasikan model sebagai berikut:

$$
\begin{aligned}
& \frac{d S}{d t}=\Lambda-\beta_{1} S I-\beta_{2} S R_{I}-\beta_{3} S H-\mu S \\
& \frac{d E}{d t}=\beta_{1} S I+\beta_{2} S R_{I}+\beta_{3} S H-\delta E-\mu E \\
& \frac{d I}{d t}=\delta E-\rho_{1} \gamma_{1} I-\left(1-\rho_{1}\right) \gamma_{1} I-\psi I-\mu I \\
& \frac{d H}{d t}=\psi I-\rho_{2} \gamma_{2} H-\left(1-\rho_{2}\right) \gamma_{2} H-\mu H \\
& \frac{d R_{I}}{d t}=\rho_{1} \gamma_{1} I-\omega R_{I} \\
& \frac{d R_{B}}{d t}=\omega R_{I}+\rho_{2} \gamma_{2} H \\
& \frac{d R_{R}}{d t}=\left(1-\rho_{1}\right) \gamma_{1} I+\left(1-\rho_{2}\right) \gamma_{2} H .
\end{aligned}
$$


dengan $S, E, I, H, R_{I}, R_{B}, R_{R} \geq 0$ dan $\Lambda, \beta_{1}, \beta_{2}, \beta_{3}, \delta, \gamma_{1}, \gamma_{2}, \psi, \rho_{1}, \rho_{2}, \omega, \mu>0$.

\section{Titik Setimbang Model}

Pada perhitungan secara analitik, persamaan (1.f) dan (1.g) diabakan karena tidak mempengaruhi sistem. Model matematika penyebaran penyakit ebola dengan penanganan medis memiliki dua titik setimbang, yaitu titik setimbang non endemik $\left(E_{0}\right)$ dan titik setimbang endemik $\left(E_{1}\right)$. Adapun titik setimbang non endemik dari model tersebut adalah $E_{0}=\left(S, E, I, H, R_{I}\right)=\left(\frac{\Lambda}{\mu}, 0,0,0,0\right)$. Dengan menggunakan metode Next Generation Matrix [7] dapat diperoleh bilangan reproduksi dasar $\left(R_{0}\right)$ sebagai berikut.

$$
R_{0}=\frac{\Lambda \delta\left[\beta_{3} \psi \omega+\left(\gamma_{2}+\mu\right)\left(\beta_{1} \omega+\beta_{2} \rho_{1} \gamma_{1}\right)\right]}{\mu(\delta+\mu)\left(\gamma_{1}+\psi+\mu\right)\left(\gamma_{2}+\mu\right) \omega}
$$

Dari hasil perhitungan diperoleh titik setimbang endemik dari model tersebut adalah sebagai berikut $E_{1}=\left(S^{*}, E^{*}, I^{*}, H^{*}, R_{I}^{*}\right)$.

$$
\begin{aligned}
S^{*} & =\frac{(\delta+\mu)\left(\gamma_{1}+\psi+\mu\right) \omega\left(\gamma_{2}+\mu\right)}{\delta\left[\beta_{1} \omega\left(\gamma_{2}+\mu\right)+\beta_{2} \rho_{1} \gamma_{1}\left(\gamma_{2}+\mu\right)+\beta_{3} \psi \omega\right]} \\
E^{*} & =\frac{\left(\gamma_{1}+\psi+\mu\right) I^{*}}{\delta} \\
I^{*} & =\frac{\Lambda \delta}{(\delta+\mu)\left(\gamma_{1}+\psi+\mu\right)}-\frac{\mu \omega\left(\gamma_{2}+\mu\right)}{\beta_{1} \omega\left(\gamma_{2}+\mu\right)+\beta_{2} \rho_{1} \gamma_{1}\left(\gamma_{2}+\mu\right)+\beta_{3} \psi \omega} \\
H^{*} & =\frac{\psi I^{*}}{\left(\gamma_{2}+\mu\right)} \\
R_{I}^{*} & =\frac{\rho_{1} \gamma_{1} I^{*}}{\omega}
\end{aligned}
$$

Berdasarkan uraian diatas, titik setimbang endemik $\left(E_{1}\right)$ akan eksis atau ada jika memenuhi syarat eksistensi, yaitu $I^{*}>0$.

$$
\begin{aligned}
& I^{*}=\left(\frac{\Lambda \delta}{(\delta+\mu)\left(\gamma_{1}+\psi+\mu\right)}-\frac{\mu \omega\left(\gamma_{2}+\mu\right)}{\beta_{1} \omega\left(\gamma_{2}+\mu\right)+\beta_{2} \rho_{1} \gamma_{1}\left(\gamma_{2}+\mu\right)+\beta_{3} \psi \omega}\right)>0, \\
& \text { dengan } \frac{\Lambda \delta}{(\delta+\mu)\left(\gamma_{1}+\psi+\mu\right)}>\frac{\mu \omega\left(\gamma_{2}+\mu\right)}{\beta_{1} \omega\left(\gamma_{2}+\mu\right)+\beta_{2} \rho_{1} \gamma_{1}\left(\gamma_{2}+\mu\right)+\beta_{3} \psi \omega} \\
& \Leftrightarrow \frac{\Lambda \delta\left[\beta_{1} \omega\left(\gamma_{2}+\mu\right)+\beta_{2} \rho_{1} \gamma_{1}\left(\gamma_{2}+\mu\right)+\beta_{3} \psi \omega\right]}{(\delta+\mu)\left(\gamma_{1}+\psi+\mu\right) \mu \omega\left(\gamma_{2}+\mu\right)}>1 \\
& \Leftrightarrow \frac{\Lambda \delta\left[\left(\beta_{1} \omega+\beta_{2} \rho_{1} \gamma_{1}\right)\left(\gamma_{2}+\mu\right)+\beta_{3} \psi \omega\right]}{(\delta+\mu)\left(\gamma_{1}+\psi+\mu\right) \mu \omega\left(\gamma_{2}+\mu\right)}>1
\end{aligned}
$$


Dari perhitungan di atas diperoleh $R_{0}>1$. Dengan demikian titik setimbang endemik $E_{1}$, eksis jika memenuhi $R_{0}>1$.

\section{$4 \quad$ Kestabilan Lokal Titik Setimbang}

Pada bagian ini akan dilakukan analisis kestabilan pada kedua titik setimbang model, yaitu titik setimbang non endemik $E_{0}$ dan titik setimbang endemik $E_{1}$.

Analisis kestabilan lokal titik setimbang non endemik diawali dengan mensubstitusikan nilai titik setimbang non endemik $E_{0}=\left(S, E, I, H, R_{I}\right)=\left(\frac{\Lambda}{\mu}, 0,0,0,0\right)$ ke dalam matriks Jacobian, dengan demikian diperoleh

$$
J_{E_{0}}=\left(\begin{array}{ccccc}
-\mu & 0 & -\beta_{1} \frac{\Lambda}{\mu} & -\beta_{3} \frac{\Lambda}{\mu} & -\beta_{2} \frac{\Lambda}{\mu} \\
0 & -\delta-\mu & \beta_{1} \frac{\Lambda}{\mu} & \beta_{3} \frac{\Lambda}{\mu} & \beta_{2} \frac{\Lambda}{\mu} \\
0 & \delta & -\gamma_{1}-\psi-\mu & 0 & 0 \\
0 & 0 & \psi & -\gamma_{2}-\mu & 0 \\
0 & 0 & \rho_{1} \gamma_{1} & 0 & -\omega
\end{array}\right) .
$$

Berdasarkan matriks Jacobian $J_{E_{0}}$, dapat dibentuk persamaan karakteristik sebagai berikut:

$$
\begin{aligned}
& \operatorname{det}\left(\lambda I-J_{E_{0}}\right)=0 . \\
& \operatorname{det}\left(\begin{array}{ccccc}
\lambda-(-\mu) & 0 & -\left(-\beta_{1} \frac{\Lambda}{\mu}\right) & -\left(-\beta_{3} \frac{\Lambda}{\mu}\right) & -\left(-\beta_{2} \frac{\Lambda}{\mu}\right) \\
0 & \lambda-(-\delta-\mu) & -\beta_{1} \frac{\Lambda}{\mu} & -\beta_{3} \frac{\Lambda}{\mu} & -\beta_{2} \frac{\Lambda}{\mu} \\
0 & -\delta & \lambda-\left(-\gamma_{1}-\psi-\mu\right) & 0 & 0 \\
0 & 0 & -\psi & \lambda-\left(-\gamma_{2}-\mu\right) & 0 \\
0 & 0 & -\rho_{1} \gamma_{1} & 0 & \lambda-(-\omega)
\end{array}\right) \\
& \Leftrightarrow(\lambda+\mu)\left[\lambda^{4}+a_{1} \lambda^{3}+a_{2} \lambda^{2}+a_{3} \lambda+a_{4}\right]=0 \\
& \operatorname{dengan} \\
& a_{1}=\gamma_{2}+2 \mu+\gamma_{1}+\psi+\omega+\delta+\mu
\end{aligned}
$$




$$
\begin{gathered}
a_{2}=\left(\gamma_{2}+\mu\right)\left(\gamma_{1}+\psi+\mu\right)+(\omega+\delta+\mu)\left(\gamma_{2}+2 \mu+\gamma_{1}+\psi\right)+(\delta+\mu) \omega-\frac{\delta \beta_{1} \Lambda}{\mu} \\
\begin{aligned}
& a_{3}=(\omega+\delta+\mu)\left(\gamma_{2}+\mu\right)\left(\gamma_{1}+\psi+\mu\right)+(\delta+\mu) \omega\left(\gamma_{2}+2 \mu+\gamma_{1}+\psi\right) \\
&-\left(\frac{\delta \beta_{3} \Lambda \psi}{\mu}+\frac{\delta \beta_{1} \Lambda}{\mu}\left(\gamma_{2}+\mu+\omega\right)+\frac{\delta \rho_{1} \gamma_{1} \beta_{2} \Lambda}{\mu}\right) \\
& a_{4}=(\delta+\mu) \omega\left(\gamma_{2}+\mu\right)\left(\gamma_{1}+\psi+\mu\right) \\
&-\left(\frac{\delta \beta_{3} \Lambda \psi}{\mu} \omega+\frac{\delta \beta_{1} \Lambda}{\mu}\left(\gamma_{2}+\mu\right) \omega+\frac{\delta \rho_{1} \gamma_{1} \beta_{2} \Lambda}{\mu}\left(\gamma_{2}+\mu\right)\right) .
\end{aligned}
\end{gathered}
$$

Berdasarkan persamaan (3), diperoleh nilai eigen $\lambda_{1}=-\mu$, dan sisanya adalah akar-akar dari persamaan berikut.

$$
\lambda^{4}+a_{1} \lambda^{3}+a_{2} \lambda^{2}+a_{3} \lambda+a_{4}
$$

Titik setimbang non endemik akan stabil asimtotis jika dan hanya jika persamaan karakteristik (3) memiliki akar-akar bagian real negatif. Jelas bahwa $\lambda_{1}$ bernilai negatif karena semua parameter seperti yang telah dijelaskan bernilai positif. Kemudian akan ditentukan persamaan (4) memiliki akar-akar bagian real negatif, yaitu dengan menggunakan kriteria Routh-Hurwitz [8]. Berdasarkan kriteria Routh-Hurwitz, titik setimbang non endemik akan stabil asimtotis jika dan hanya jika $R_{i}<1$, dengan $i=$ $0,1,2,3$.

$$
\begin{aligned}
& R_{0}=\frac{\Lambda \delta\left[\beta_{3} \psi \omega+\left(\beta_{1} \omega+\beta_{2} \rho_{1} \gamma_{1}\right)\left(\gamma_{2}+\mu\right)\right]}{\mu(\delta+\mu) \omega\left(\gamma_{2}+\mu\right)\left(\gamma_{1}+\psi+\mu\right)}, \\
& R_{1}=\frac{\delta \beta_{1} \Lambda}{\mu\left[\left(\gamma_{2}+\mu\right)\left(\gamma_{1}+\psi+\mu\right)+(\omega+\delta+\mu)\left(\gamma_{2}+2 \mu+\gamma_{1}+\psi\right)+(\delta+\mu) \omega\right]} \\
& R_{2}=\frac{\delta \beta_{3} \Lambda \psi+\delta \beta_{1} \Lambda\left(\gamma_{2}+\mu+\omega\right)+\delta \rho_{1} \gamma_{1} \beta_{2} \Lambda}{\mu\left[(\omega+\delta+\mu)\left(\gamma_{2}+\mu\right)\left(\gamma_{1}+\psi+\mu\right)+(\delta+\mu) \omega\left(\gamma_{2}+2 \mu+\gamma_{1}+\psi\right)\right]} \\
& R_{3}=\frac{a_{1}^{2} a_{4}+a_{3}^{2}}{a_{1} a_{2} a_{3}}
\end{aligned}
$$

Hal ini menunjukkan bahwa penyakit akan menghilang dari populasi atau tidak ada penyebaran penyakit atau tidak ada penyebaran penyakit.

Berikutnya, analisis kestabilan titik setimbang endemik sulit dilakukan secara analitik karena persamaan yang dihasilkan rumit dan bergantung pada variabel $I$, sehingga akan dilakukan analisis secara numerik dengan menggunakan bidang fase.

Adapun nilai parameter dan nilai awal berturut-turut disajikan pada Tabel 2 dan 3. 
Tabel 2 Nilai Parameter Model

\begin{tabular}{cccc}
\hline Parameter & Nilai & Satuan & Sumber \\
\hline$\Lambda$ & 400 & $\frac{\text { orang }}{\text { hari }}$ & {$[5]$} \\
$\beta_{1}$ & 0.376 & $\frac{1}{\text { hari }}$ & {$[6]$} \\
$\beta_{2}$ & 0.135 & $\frac{1}{\text { hari }}$ & {$[6]$} \\
$\beta_{3}$ & 0.163 & $\frac{1}{\text { hari }}$ & {$[6]$} \\
$\delta$ & $\frac{1}{\text { hari }}$ & {$[6]$} \\
$\gamma_{1}$ & 0.0542 & $\frac{1}{\text { hari }}$ & {$[6]$} \\
$\gamma_{2}$ & 0.174 & $\frac{1}{\text { hari }}$ & {$[6]$} \\
$\psi$ & 0.5 & $\frac{1}{\text { hari }}$ & {$[6]$} \\
$\rho_{1}$ & 0.98 & $\frac{1}{\text { hari }}$ & {$[6]$} \\
$\rho_{2}$ & 0.88 & $\frac{1}{\text { hari }}$ & {$[6]$} \\
$\omega$ & 0.325 & $\frac{1}{\text { hari }}$ & $[6])$ \\
& & $\frac{1}{\text { hari }}$ & \\
& 0.0004 & &
\end{tabular}

Tabel 3. Nilai Awal

\begin{tabular}{ccccccccc}
\hline Nilai Awal & $\boldsymbol{S}(\mathbf{0})$ & $\boldsymbol{E}(\mathbf{0})$ & $\boldsymbol{I}(\mathbf{0})$ & $\boldsymbol{H}(\mathbf{0})$ & $\boldsymbol{R}_{\boldsymbol{I}}(\mathbf{0})$ & $\boldsymbol{R}_{\boldsymbol{R}}(\mathbf{0})$ & $\boldsymbol{R}_{\boldsymbol{B}}(\mathbf{0})$ & Warna \\
\hline Nilai Awal 1 & 980 & 508 & 137 & 49 & 122 & 12 & 3 & Biru \\
Nilai Awal 2 & 1250 & 700 & 250 & 150 & 200 & 30 & 10 & Hijau \\
Nilai Awal 3 & 90 & 45 & 10 & 3 & 7 & 2 & 1 & Merah \\
\hline
\end{tabular}

Hasil simulasi bidang fase pada titik setimbang endemik model matematika penyebaran penyakit ebola dengan penanganan medis ditunjukkan pada Gambar 2. 


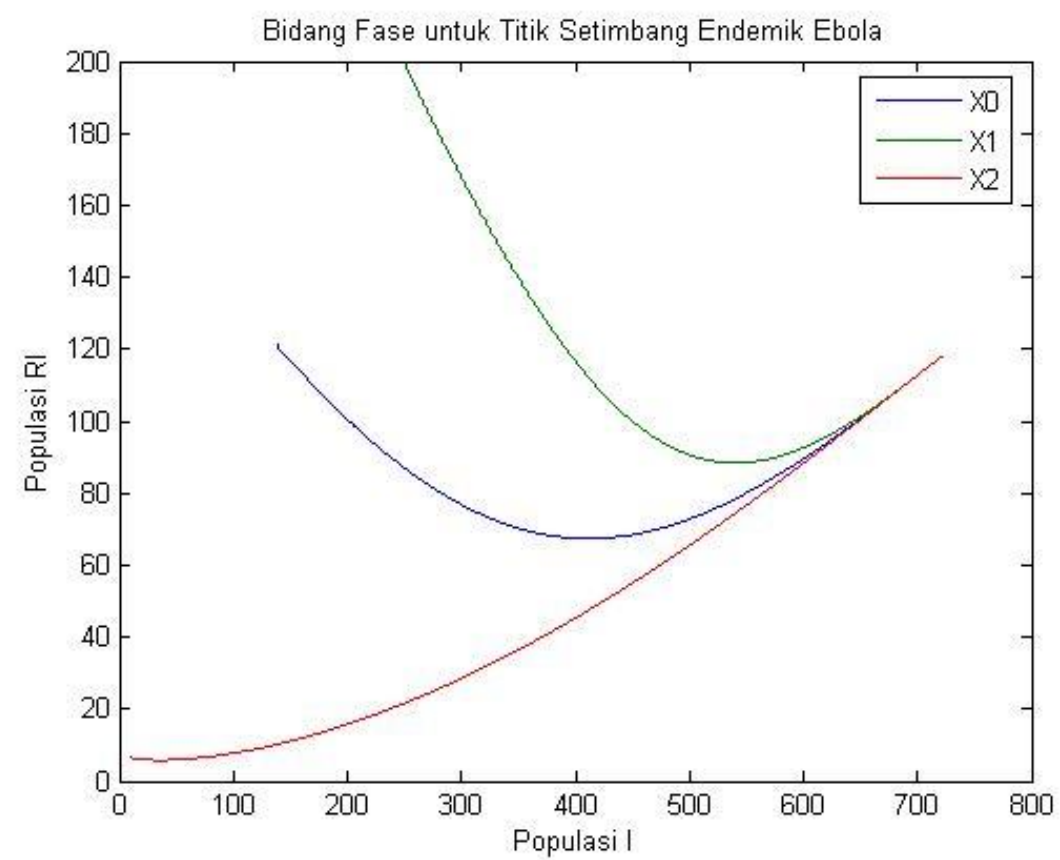

Gambar 2. Simulasi Bidang Fase pada Bidang $I-R_{I}$ untuk Titik Setimbang Endemik Model

Gambar 2 menunjukkan simulasi bidang fase untuk populasi manusia yang terinfeksi virus ebola ( $I$ ) dan populasi manusia terinfeksi yang mati dan belum mendapat penguburan dengan baik $\left(R_{I}\right)$ pada model matematika penyebaran penyakit ebola dengan penanganan medis. Dari Gambar 2 menunjukkan dari waktu ke waktu $(t)$ nilai $I$ dan $R_{I}$ cenderung menuju ke suatu titik yaitu $I \rightarrow 721$ dan $R_{I} \rightarrow 117$ atau cenderung stabil asimtotis ke titik $(721,118)$ yang tidak lain merupakan bagian dari titik setimbang endemik $E_{1}=\left(S^{*}, E^{*}, I^{*}, H^{*}, R_{I}^{*}\right)=(1,3590,721,2073,118)$. Nilai $E_{1}$ diperoleh melalui substitusi nilai parameter pada titik setimbang endemik yang telah diperoleh secara analitik.

Selain diperoleh nilai $E_{1}$, berdasarkan perhitungan analitik pada bilangan reproduksi dasar $\left(R_{0}\right)$ diperoleh sebagai berikut

$R_{0}=\frac{\Lambda \delta\left[\beta_{3} \psi \omega+\left(\gamma_{2}+\mu\right)\left(\beta_{1} \omega+\beta_{2} \rho_{1} \gamma_{1}\right)\right]}{\mu(\delta+\mu)\left(\gamma_{1}+\psi+\mu\right)\left(\gamma_{2}+\mu\right) \omega}=3.1886 \times 10^{8}$

Berdasarkan penjelasan di atas, maka titik setimbang endemik $E_{1}=\left(S^{*}, E^{*}, I^{*}, H^{*}, R_{I}^{*}\right)$ pada model matematika penyebaran penyakit ebola dengan penanganan medis cenderung stabil asimtotis jika dan hanya jika $R_{0}>1$. Hal ini menunjukkan bahwa terjadi penyebaran penyakit ebola. 


\section{$5 \quad$ Analisis Masalah Kontrol Optimal}

Model matematika penyebaran penyakit ebola dengan penanganan medis ini dikembangkan dengan penambahan variabel kontrol berupa upaya pengobatan. Berikut adalah model matematika penyebaran penyakit ebola dengan penanganan medis dengan variabel kontrol $u$ :

$$
\begin{aligned}
& \frac{d S}{d t}=\Lambda-\beta_{1} S I-\beta_{2} S R_{I}-\beta_{3} S H-\mu S \\
& \frac{d E}{d t}=\beta_{1} S I+\beta_{2} S R_{I}+\beta_{3} S H-\delta E-\mu E \\
& \frac{d I}{d t}=\delta E-u \rho_{1} \gamma_{1} I-u\left(1-\rho_{1}\right) \gamma_{1} I-\psi I-\mu I \\
& \frac{d H}{d t}=\psi I-u \rho_{2} \gamma_{2} H-u\left(1-\rho_{2}\right) \gamma_{2} H-\mu H \\
& \frac{d R_{I}}{d t}=u \rho_{1} \gamma_{1} I-\omega R_{I} \\
& \frac{d R_{B}}{d t}=\omega R_{I}+u \rho_{2} \gamma_{2} H \\
& \frac{d R_{R}}{d t}=u\left(1-\rho_{1}\right) \gamma_{1} I+u\left(1-\rho_{2}\right) \gamma_{2} H
\end{aligned}
$$

Variabel dan parameter yang digunakan telah diuraikan pada Subbab 2 dan Tabel 1. Dari model tersebut dapat diketahui bahwa terdapat penambahan variabel berupa variabel kontrol $u$, variabel ini berupa upaya pengobatan. Fungsi ongkos atau indeks performansi yang dapat dibentuk berdasarkan penjelasan di atas adalah sebagai berikut:

$$
\operatorname{Min} J=\int_{0}^{t f}\left(I+H+\frac{A}{2} u^{2}\right) d t
$$

dengan koefisien $A$ adalah konstanta pembobot berupa biaya yang harus dikeluarkan untuk upaya pengobatan. Batas kontrol optimal berada pada $0 \leq u(t) \leq 1,0 \leq t \leq t_{f}$ serta $t_{f}$ merupakan waktu akhir.

\subsection{Penyelesaian Kontrol Optimal}

Berdasarkan Prinsip Maksimum Pontryagin [9, 10], langkah pertama yang dilakukan adalah membentuk fungsi Hamiltonian pada model sebagai berikut:

$$
\mathcal{H}=I+H+\frac{A}{2} u^{2}+\lambda^{T}(t)(f(x(t), u(t), t))
$$


dengan $f(x(t), u(t), t)$ adalah ruas kanan dari model matematika penyebaran penyakit ebola dengan penanganan medis yang disertai variabel kontrol, sedangkan $\lambda^{T}(t)$ menyatakan pengali Lagrange atau variabel co-state.

Selanjutnya, agar diperoleh kondisi optimal maka fungsi Hamiltonian harus memenuhi kondisi stasioner yaitu $\frac{\partial \mathcal{H}}{\partial u}=0$, maka didapatkan

$\Leftrightarrow A u-\lambda_{3}\left[\rho_{1} \gamma_{1} I+\left(1-\rho_{1}\right) \gamma_{1} I\right]-\lambda_{4}\left[\rho_{2} \gamma_{2} H+\left(1-\rho_{2}\right) \gamma_{2} H\right]+\lambda_{5} \rho_{1} \gamma_{1} I+$ $\lambda_{6} \rho_{2} \gamma_{2} H+\lambda_{7}\left[\left(1-\rho_{1}\right) \gamma_{1} I+\left(1-\rho_{2}\right) \gamma_{2} H\right]=0$

$\Leftrightarrow u=\frac{\left(\lambda_{3}-\lambda_{7}\right) \gamma_{1} I+\left(\lambda_{4}-\lambda_{7}\right) \gamma_{2} H+\left(\lambda_{7}-\lambda_{5}\right) \rho_{1} \gamma_{1} I+\left(\lambda_{7}-\lambda_{6}\right) \rho_{2} \gamma_{2} H}{A}$.

Oleh karena $0 \leq u(t) \leq 1$, maka terdapat beberapa kemungkinan nilai untuk $u$ adalah sebagai berikut:

$u^{*}=\left\{\begin{array}{cl}0 & \text { untuk } u^{*} \leq 0 \\ \frac{\left(\lambda_{3}-\lambda_{7}\right) \gamma_{1} I+\left(\lambda_{4}-\lambda_{7}\right) \gamma_{2} H+\left(\lambda_{7}-\lambda_{5}\right) \rho_{1} \gamma_{1} I+\left(\lambda_{7}-\lambda_{6}\right) \rho_{2} \gamma_{2} H}{A} & \text { untuk } 0<u^{*}<1 \\ 1 & \text { untuk } u^{*} \geq 0\end{array}\right.$

Berdasarkan kemungkinan diatas, maka diperoleh nilai kontrol yang optimal adalah sebagai berikut

$$
u^{*}=\min \left(1, \max \left(0, \frac{\left(\lambda_{3}-\lambda_{7}\right) \gamma_{1} I+\left(\lambda_{4}-\lambda_{7}\right) \gamma_{2} H+\left(\lambda_{7}-\lambda_{5}\right) \rho_{1} \gamma_{1} I+\left(\lambda_{7}-\lambda_{6}\right) \rho_{2} \gamma_{2} H}{A}\right)\right)
$$

Selanjutnya, karena dalam bentuk pengontrol $u^{*}$ terdapat variabel state yaitu $x=$ $\left(S, E, I, H, R_{I}, R_{B}, R_{R}\right)^{T}$, maka perlu diselesaikan persamaan state dan persamaan co-state untuk memperoleh variabel tersebut. Dengan demikian akan ditentukan penyelesaian persamaan state untuk memperoleh variabel tersebut yaitu $\dot{x}=\frac{\partial \mathcal{H}}{\partial \lambda}$.

Lebih lanjut, akan ditentukan persamaan co-state pada pengontrol $u^{*}$ dapat diperoleh dari $\dot{\lambda}=-\frac{\partial \mathcal{H}}{\partial x}$. Dari sini diperoleh persamaan co-state sebagai berikut:

$\dot{\lambda_{1}}=-\frac{\partial \mathcal{H}}{\partial S}=-\left[\lambda_{1}\left(-\beta_{1} I-\beta_{2} R_{I}-\beta_{3} H-\mu\right)+\lambda_{2}\left(\beta_{1} I+\beta_{2} R_{I}+\beta_{3} H\right)\right]$

$\dot{\lambda_{2}}=-\frac{\partial \mathcal{H}}{\partial E}=-\left[\lambda_{2}(-\delta-\mu)+\lambda_{3} \delta\right]$ 


$$
\begin{aligned}
& \dot{\lambda_{3}}=-\frac{\partial \mathcal{H}}{\partial I}=-\left[-\lambda_{1} \beta_{1} S+\lambda_{2} \beta_{1} S+\lambda_{3}\left(-u \rho_{1} \gamma_{1}-u\left(1-\rho_{1}\right) \gamma_{1}-\psi-\mu\right)+\lambda_{4} \psi+\right. \\
& \left.\lambda_{5} u \rho_{1} \gamma_{1}+\lambda_{7} u\left(1-\rho_{1}\right) \gamma_{1}\right] \\
& \dot{\lambda_{4}}=-\frac{\partial \mathcal{H}}{\partial H}=-\left[-\lambda_{1} \beta_{3} S+\lambda_{2} \beta_{3} S+\lambda_{4}\left(-u \rho_{2} \gamma_{2}-u\left(1-\rho_{2}\right) \gamma_{2}-\mu\right)+\lambda_{6} u \rho_{2} \gamma_{2}+\right. \\
& \left.\lambda_{7} u\left(1-\rho_{2}\right) \gamma_{2}\right] \\
& \dot{\lambda_{5}}=-\frac{\partial \mathcal{H}}{\partial R_{I}}=-\left[-\lambda_{1} \beta_{2} S+\lambda_{2} \beta_{2} S-\lambda_{5} \omega+\lambda_{6} \omega\right] \\
& \dot{\lambda_{6}}=-\frac{\partial \mathcal{H}}{\partial R_{B}}=0 \\
& \dot{\lambda_{7}}=-\frac{\partial \mathcal{H}}{\partial R_{R}}=0 .
\end{aligned}
$$

Berdasarkan penjelasan di atas, untuk memperoleh $S, E, I, H, R_{I}, R_{B}, R_{R}$ dari bentuk $u^{*}$ yang optimal, maka tahap yang perlu dilakukan selanjutnya adalah dengan menyelesaaikan persamaan state dan co-state yang berbentuk persamaan diferensial non linear. Karena persamaan diferensial non linear sulit diselesaikan secara analitik, maka dilakukan penyelesaian secara numerik melalui simulasi permasalahan kontrol optimal menggunakan program DOTcvp pada aplikasi MATLAB.

\subsection{Simulasi Numerik}

Simulasi ini dilakukan dengan membandingkan model matematika penyebaran penyakit ebola dengan penanganan medis tanpa adanya variabel kontrol dan dengan adanya variabel kontrol. Hal tersebut bertujuan untuk mengetahui tingkat keefektifan dari pengobatan dengan pemberian oralit yang mengandung elektrolit sehingga tujuan dari fungsi ongkos yang diberikan akan tercapai.

Kondisi model ini tanpa adanya variabel kontrol terjadi ketika pengobatan berupa pemberian oralit yang mengandung elektrolit $(u)$ sama dengan nol. Simulasi dilakukan untuk $t=0$ sampai $t=40$ hari dengan nilai awal untuk setiap kondisi adalah $S(0)=$ 980, $E(0)=508, I(0)=137, H(0)=49, R_{I}(0)=122, R_{B}(0)=12, R_{R}(0)=3$. Nilai parameter yang digunakan sama dengan nilai parameter saat mensimulasikan bidang fase untuk titik setimbang endemik. Konstanta pembobot untuk pengobatan tersebut sebesar $A=1000$.

Gambar 3 menujukkan bahwa terdapat perbedaan antara populasi individu terinfeksi (Infected) serta populasi terinfeksi dan mendapat penanganan di rumah sakit (Hospitalized) pada model tanpa adanya variabel kontrol dan model dengan adanya variabel kontrol. Jumlah kedua populasi individu dengan kontrol $u$ cenderung lebih sedikit dibandingkan tanpa control. 

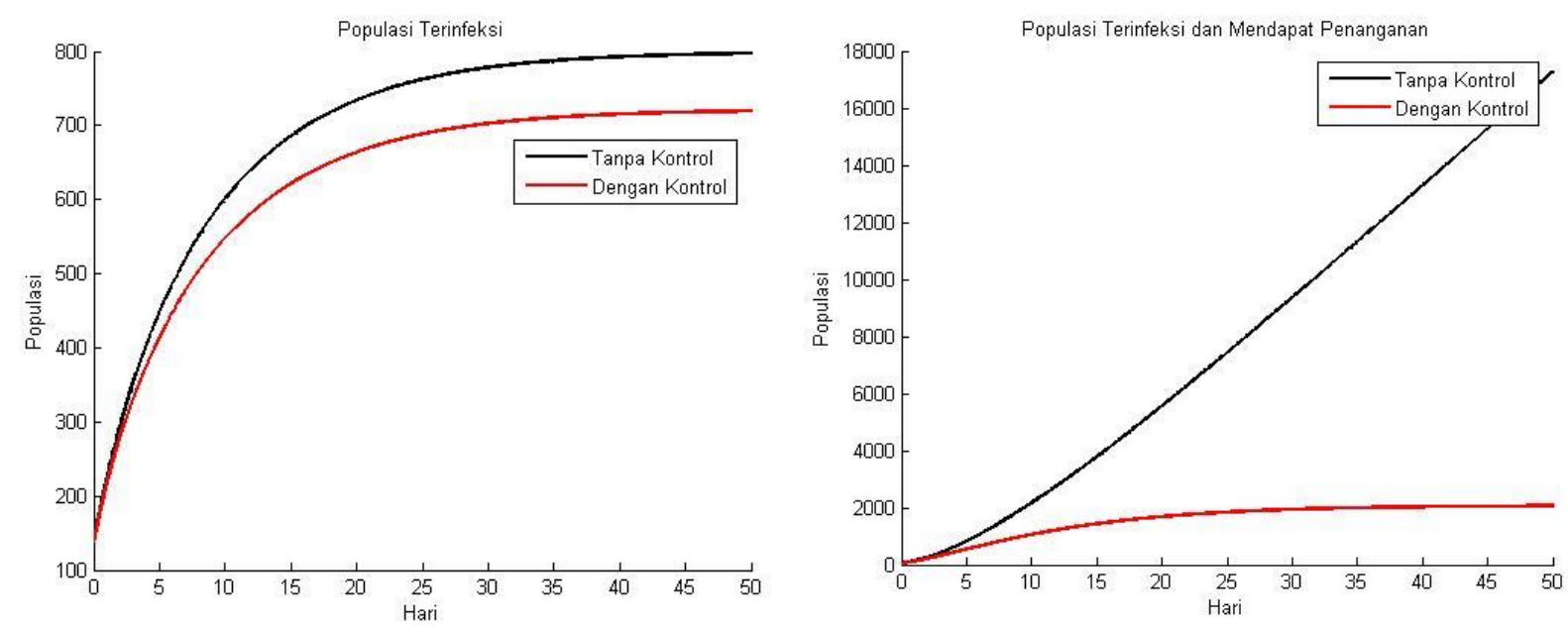

Gambar 3. Simulasi Perbandingan Populasi terinfeksi (Infected) (Kiri) dan Populasi Terinfeksi dan Mendapat Penanganan di Rumah Sakit (Hospitalized) (Kanan)

Selanjutnya simulasi untuk profil kontrol akan disajikan pada Gambar 4. Pada Gambar 4 terlihat bahwa pemberian kontrol $u$ yaitu upaya pengobatan dalam jangka waktu 50 hari. Dari awal pengamatan hingga hari ke-10 upaya pengobatan terus menerus naik, pada hari ke-11 hingga hari ke-46 upaya pengobatan dilakukan secara maksimal, dan menuju akhir pengamatan upaya mengalami penurunan hingga mencapai $50 \%$.

Dengan demikian dapat disimpulkan bahwa untuk menimimumkan populasi individu yang terinfeksi (Infected) dan populasi individu terinfeksi yang mendapat penanganan di rumah sakit (Hospitalized) serta biaya yang dikeluarkan upaya pengobatan maka langkah yang pemberian upaya pengobatan itu sendiri. Tindakan ini menimumkan populasi individu yang terinfeksi (Infected) dan populasi individu terinfeksi yang mendapat penanganan di rumah sakit (Hospitalized). 


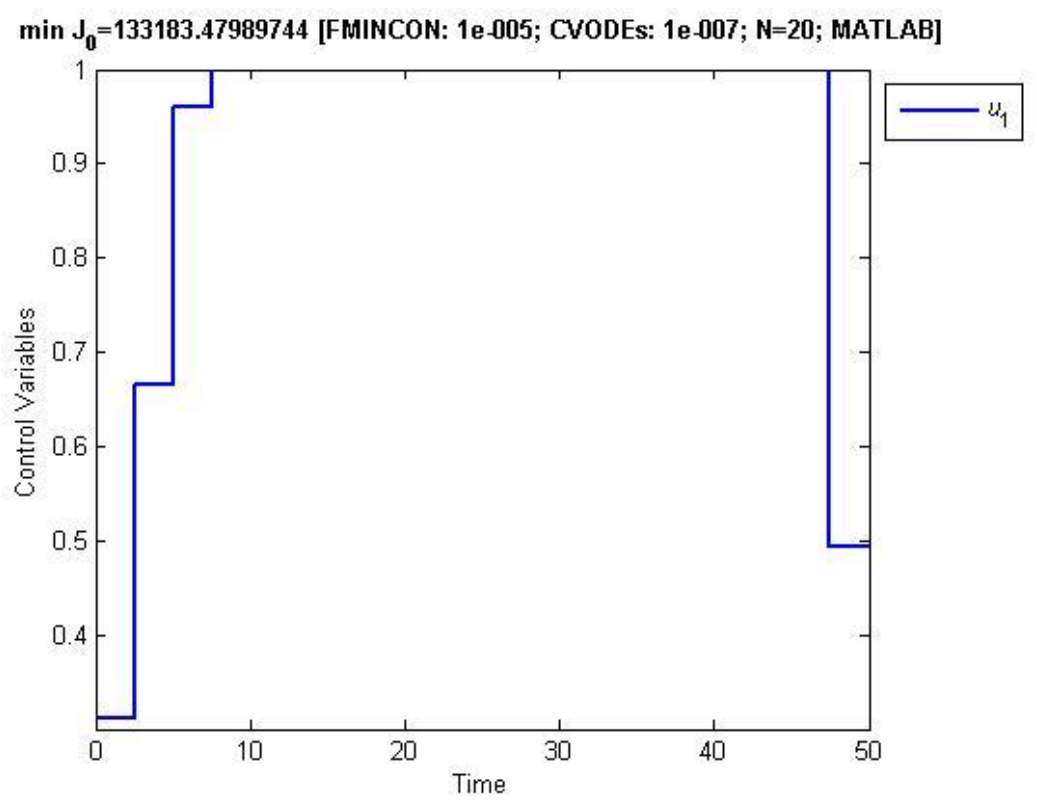

Gambar 4. Grafik Kontrol $u$

\section{Kesimpulan}

Berdasarkan hasil dan pengamatan yang telah diuraikan dapat diperoleh kesimpulan sebagai berikut:

1. Model matematika penyebaran penyakit ebola dengan penanganan medis memiliki dua titik setimbang yaitu titik setimbang non endemik $\left(E_{0}\right)$, dan titik setimbang endemik $\left(E_{1}\right)$. Titik setimbang non endemik akan stabil asimtotis jika $R_{0}<1$ dan memenuhi beberapa kondisi. Titik setimbang endemik cenderung stabil asimtotis jika memenuhi $R_{0}>1$, dengan

$$
R_{0}=\frac{\Lambda \delta\left[\beta_{3} \psi \omega+\left(\gamma_{2}+\mu\right)\left(\beta_{1} \omega+\beta_{2} \rho_{1} \gamma_{1}\right)\right]}{\mu(\delta+\mu)\left(\gamma_{1}+\psi+\mu\right)\left(\gamma_{2}+\mu\right) \omega} .
$$

2. Berdasarkan hasil simulasi secara numerik pada model matematika penyebaran penyakit ebola dengan penanganan medis sebelum dan setelah diberi kontrol berupa upaya pengobatan, dapat meminimalkan jumlah manusia yang terinfeksi virus ebola dan populasi individu terinfeksi yang mendapat penanganan di rumah sakit dibandingkan tanpa kontrol. 


\section{$7 \quad$ Daftar Pustaka}

[1] World Health Organization, Ebola Virus Disease, https://www.who.int/, 13 Maret 2018.

[2] Centers for Disease Control and Prevention, Ebola Hemorrhagic Fever, https://www.cdc.gov/, 13 Maret 2018

[3] Carrroll, S.A., Towner, J.S., Sealy, T.K., Mcmullan, L.K., Khristova, Burt, F.J., Swanepoel, R., Roliing, P.E., dan Nichol, S.T., 2013, Molecular Evolution of Viruses of the Family Filoviridae Based on 97 Whole-Genome Sequences, Journal of Virology, 87: 2608-2616.

[4] Do, Tae Sug dan Lee, Young S., 2016, Modeling the Spread of Ebola, Osong Public Health and Research Perspectives, 7: 43-48.

[5] Agusto, F.B., 2017, Mathematical Model of Ebola Transmission Dynamics with Relapse and Reinfection, Mathematical Biosciences, 283: 48-59.

[6] Diaz, P., Constantine, P., Kalmbach, K., Jones, E., dan Pankavich, S., 2018, A Modified SEIR Model for The Spread of Ebola in Western Africa and Metrics for Resource Allocation, Applied Mathematics and Computation, 324: 141-155.

[7] van den Driessche P dan Watmough, J., 2002, Reproduction numbers and subthreshold endemic equilibria for compartmental models of disease transmission, Mathematical Biosciences, 180:29-48.

[8] Merkin, D. R., 1997, Introduction to The Theory of Stability, Springer, New York.

[9] Lewis, F.I., dan Syrmos, V. L., 2006, Optimal Control, Willy Interscience, Canada.

[10] Naidu, D.S., 2002, Optimal Control Systems, CRC Press LCC, New York. 